\title{
Bathyal ostracods from the Santa Maria di Leuca deep-water coral province (northern Ionian Sea)
}

\author{
Francesco Sciuto and Antonietta Rosso
}

\begin{abstract}
Living and dead deep-water ostracods from different sites and habitats of the Cold Water Coral Province off Santa Maria di Leuca have been investigated. A total of 42 ostracod taxa were determined, 34 of which at species level and 8 at genus level. The living associations comprise only two species: Bairdoppilata conformis and Bythocypris obtusata. The same species form dead associations together with Henryhowella ex $\mathrm{H}$. hirta group, Macropyxis adriatica, Bythocypris bosquetiana, Pseudocythere caudata, Bathycythere vanstraateni and Cytheropteron testudo. The analysis of dead assemblages, which includes species such as Bathycythere vanstraateni, Cytheropteron testudo, and Bythocythere mylaensis - taxa no longer thriving in the Recent Mediterranean Sea - allowed us to determine that an old component of the ostracod assemblages of the "Santa Maria di Leuca Cold Water Coral Province" seemingly lived during the last cold period of the Late Pleistocene or its transition to the Holocene. Furthermore, the high species richness and specimen abundance, recorded in some samples, might be related to a local increase in the availability of trophic resources at the bottom surface related to the general circulation and to the presence of deep coral bioconstructions. The presence of a few carapaces of species with shallower distributions seems related to post mortem displacement events.
\end{abstract}

Francesco Sciuto. University of Catania. Palaeoecological Research Group. Department of Biological, Geological and Environmental Sciences, Corso Italia, 57.95129 Catania. fsciuto@unict.it

Antonietta Rosso. University of Catania. Palaeoecological Research Group. Department of Biological, Geological and Environmental Sciences, Corso Italia, 57.95129 Catania.rosso@unict.it

Keywords: Deep-water ostracods; Coral mounds; Ionian Sea; Mediterranean Sea; Pleistocene-Holocene

\section{INTRODUCTION}

An area in which deep water corals develop was discovered off Santa Maria di Leuca (northern Ionian Sea, Apulian Margin). The Santa Maria di Leuca Cold Water Coral province (SML CWC province) develops on the continental slope from about
400 to about $1200 \mathrm{~m}$ wd, on the Apulian Ridge (Figure 1) (Taviani et al., 2005; Mastrototaro et al., 2010; Rosso et al., 2010). This area has been intensively studied in recent years, and researchers allowed to define seafloor morphology, dominant sedimentary processes as well as the extent 


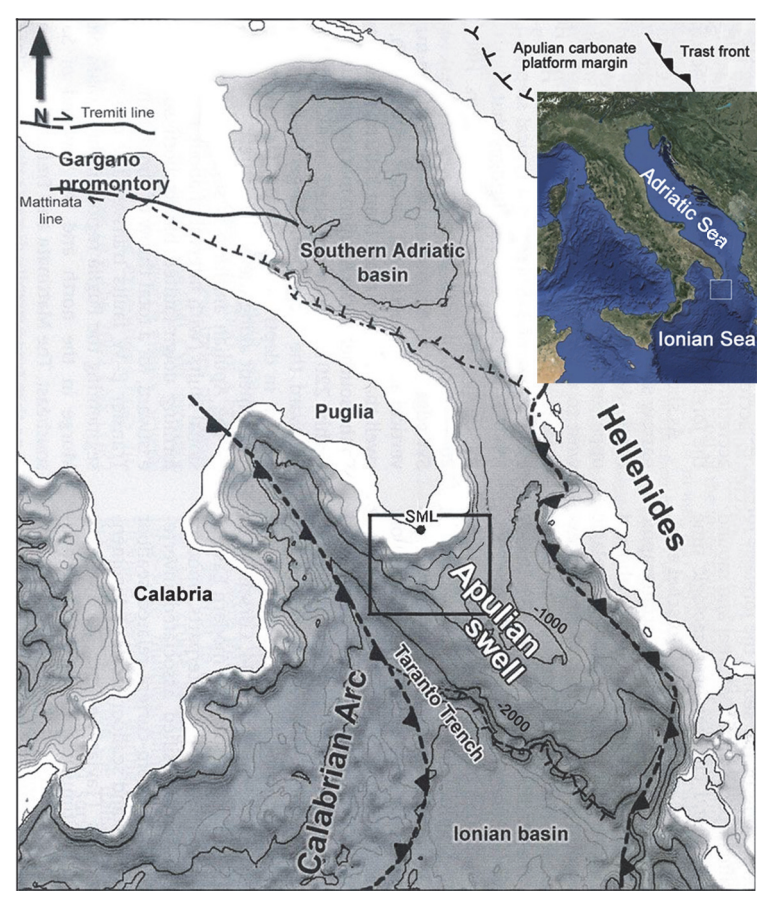

FIGURE 1. Location of the study area and Geological setting of the Apulian swell (after Savini and Corselli, 2010, modified).

and pattern of cold-water coral distribution (Corselli, 2010). In particular, it has been found that deep water coral growth creates patches of colonies settled on the northern flanks and/or near the top of mound structures (Rosso et al., 2010; Vertino et al., 2010). Deep bioconstructions consist of living and dead colonies of Madrepora oculata Linnaeus, 1758 associated with Lophelia pertusa (Linnaeus, 1758) and Desmophyllum dianthus (Esper, 1788). Bioconstruction grow on Pleistocene consolidated sediments and shell lags (Taviani et al., 2005; Malinverno et al., 2010; Rosso et al., 2010; Vertino et al., 2010). Mounds hosting the deep scleractinian or "white corals" community are bounded by several sedimentary facies, mostly bioclastic and coarse-grained, which represent the transition to neighbouring bathyal bottoms characterised by pelagic sedimentation (Rosso et al., 2010).

A few preliminary information on the ostracod fauna from the area was given in Mastrototaro et al. (2010) and in Rosso et al. (2010) concerning present day and dead associations, respectively. However, data acquired at that time and further documentation allow us to present more comprehensive information to shed light on ostracods associated to deep-water coral mounds from the Mediterranean Sea. Although bathyal ostracods have been studied in several areas from this basin (e.g., Breman, 1975; Bonaduce et al., 1983; Sciuto, 2014) nearly nothing is presently still known about ostracod communities associated with living and Recent CWC from the Mediterranean whereas some information exists about comparable Holocene association from the North Atlantic (Coles et al., 1996; Stalder et al., 2014).

The present paper aims to contribute information to fill, at least partly, this lack of information and particularly to: 1. present a systematic account on leaving and dead deep-water ostracods from the different sites and habitats of the SML deep water coral mound province; 2 . investigate structure and composition of ostracod associations and their distribution in relation to environmental features such as grain size and the availability of food, largely linked to the coral mound proximity and the presence of the scleractinian community.

\section{Geological Setting}

The Apulian continental margin (Figure 1), structurally included in the undeformed margin of the African Foreland (Apulian Block), is characterised by a complex topography strongly influenced by gravitative and current-dominated sedimentary processes (Malinverno et al., 2010; Savini and Corselli, 2010). The Continental Shelf is extremely variable in width, from a minimum of $4 \mathrm{~km}$ (Taranto) to more than $20 \mathrm{~km}$ (off SM Leuca), and is incised by several orders of Holocene terraces, the offshore edges of which have been discovered to host CWC banks (Taviani et al., 2005; Mastrototaro et al., 2010; Rosso et al., 2010).

The continental slope, eroded by canyons, is the site of intense sediment transport towards the Ionian Basin abyssal plain. Slope continuity is interrupted repeatedly by weakly inclined morphological structures where thick sedimentary accumulations form (Savini and Corselli, 2010). The most important of these sites is represented by the Apulian Swell, bounded southwestward by a deep and narrow canyon (the Taranto trench). The Apulian Swell represents a southeastward directed submarine extension of the Apulian peninsula that separates the South Adriatic Basin from the Ionian Basin (Auroux et al., 1985). On the top of the Apulian swell, $9 \mathrm{~km}$ south of SM Leuca, the coral mounds are located at depths ranging from about 505 to more than 900 metres (Corselli, 2010). Samples analyzed in the present study came from this area. 
TABLE 1. Facies and their sedimentological characters.

\begin{tabular}{|c|c|c|c|c|}
\hline \multicolumn{2}{|l|}{ Facies } & Samples & Depth & Main features \\
\hline Framework Coral & $\mathrm{FC}$ & AP01, AP030 & $512-747$ & $\begin{array}{l}\text { Biocostruction dominated by Madrepora oculata } \\
\text { Linnaeus, } 1758 \text { and Lophelia pertusa (Linnaeus, } \\
\text { 1758) colonies }\end{array}$ \\
\hline Coral Rubble & $\mathrm{CR}$ & AP07, AP15,AP17, & $525-649$ & $\begin{array}{l}\text { Silt and sandy silt mixed with abundant biogenic } \\
\text { detritus mostly derived from the fragmentation of } \\
\text { colonial corals }\end{array}$ \\
\hline Solitary Coral & $\mathrm{SC} / \mathrm{HG}$ & AP29, AP04, AP09, AP11 & $505-790$ & $\begin{array}{l}\text { Fine sediments including cobbles and pebbles and } \\
\text { hard ground fragments, both colonized by solitary } \\
\text { corals }\end{array}$ \\
\hline Gryphus and Isidella & $\mathrm{GI}$ & AP08, AP14t, AP14b & $525-530$ & $\begin{array}{l}\text { Fine-grained sediments with Gryphus vitreus (Born, } \\
\text { 1778) and Isidella elongata (Esper, 1788) }\end{array}$ \\
\hline Mollusc Mud & MM & $\begin{array}{c}\text { AP19t, AP19b, AP21t, } \\
\text { AP21b, AP22b, AP24t, } \\
\text { AP24b }\end{array}$ & $638-655$ & $\begin{array}{l}\text { Mud with dispersed mollusc shells mostly colonised } \\
\text { by Abra longicallus (Scacchi, 1835) and Ebalia }\end{array}$ \\
\hline Foraminifer Mud & FM & $\begin{array}{l}\text { AP02, AP03t, AP03b, AP05t, } \\
\text { AP05b }\end{array}$ & 506 & $\begin{array}{l}\text { Silt and bioclastic sand with foraminifers and rare } \\
\text { pteropods }\end{array}$ \\
\hline
\end{tabular}

\section{MATERIALS AND METHODS}

Twenty-five samples of bottom sediments were taken in 2006 in the lonian Sea during the cruises performed on board of the R/V Universitatis, 9 kilometres south of the S.M. di Leuca. The sampled area is included between the latitudes $39^{\circ}$ $28.09^{\prime} \mathrm{N}$ and $39^{\circ} 34.84^{\prime} \mathrm{N}$ and the longitudes $18^{\circ} 24.42^{\prime} \mathrm{E}$ and $18^{\circ} 23.30^{\prime} \mathrm{E}$ (Corselli, 2010). This area is located on the top of the northern part of the "Apulian swell" (Figure 1). Samples were collected in the depth range of 506-790 metres, mostly through a 60 litres Van Veen grab and two with a box-corer whereas further three were taken using an epibenthic modified Sanders sledge (Rosso et al., 2010) equipped with a plankton net at its end.

Following Rosso et al. (2010) and Mastrototaro et al. (2010), six different facies have been defined (Table 1, Figure 2): 1) Framework Coral facies (FC), dominated by Madrepora oculata and Lophelia pertusa colonies; 2) Coral Rubble facies (CR), consisting of silt and sandy silt mixed with abundant biogenic detritus, mostly derived from the fragmentation of colonial corals; 3) Solitary Coral facies and hard grounds (SC/HG), consisting of fine sediments with interspersed pebbles and hard ground fragments and large slabs, colonized by solitary corals; 4) Gryphus and Isidella facies (GI) mostly consisting of fine-grained sediments and including rare centimetre-sized bioclasts, with Gryphus vitreus (Born, 1778) and Isidella elongata (Esper, 1788); 5) Mollusc Mud facies (MM) consisting of mud with dispersed mollusc shells, colonised by Abra longicallus (Scacchi, 1835); and 6) Fora- minifer Mud facies (FM) consisting of silt and bioclastic sand with foraminifers and rare pteropods.

From each sample a sediment volume of 300 cc was used for the analysis of ostracod faunas. Ostracoda were picked from the $>63$ microns fraction. Entire carapaces and disarticulated valves were counted. Juveniles were scored separately. The specimens were examined and measured under a stereomicroscope and photographed through a scanning electron microscope LMU Tescan Vega II. The material is housed in the paleontological section of the Museo di Scienze della Terra of the University of Catania (PMC). Ostracod figured specimens in the Sciuto Collection under the code numbers PMC. FS. I. H. O 16-29.

\section{RESULTS}

A total of 42 ostracod taxa were detected, of which 34 were determined at species level and 8 at genus level (Appendices 1, 2).

The living community comprises only two species: Bairdoppilata conformis (Terquem, 1878) and Bythocypris obtusata (Sars, 1866) that are present in one/third of the samples. Their abundance varies from a maximum of four specimens per sample in samples AP29, AP24 and AP19t to one specimen in the sample AP01.

Dead specimens of these two species and the remaining 40 ones form dead assemblages or thanatocoenoses that are present in all the collected samples. Species richness varies greatly from a minimum of one to a maximum of 16 species per sample. In the dead assemblages it is pos- 


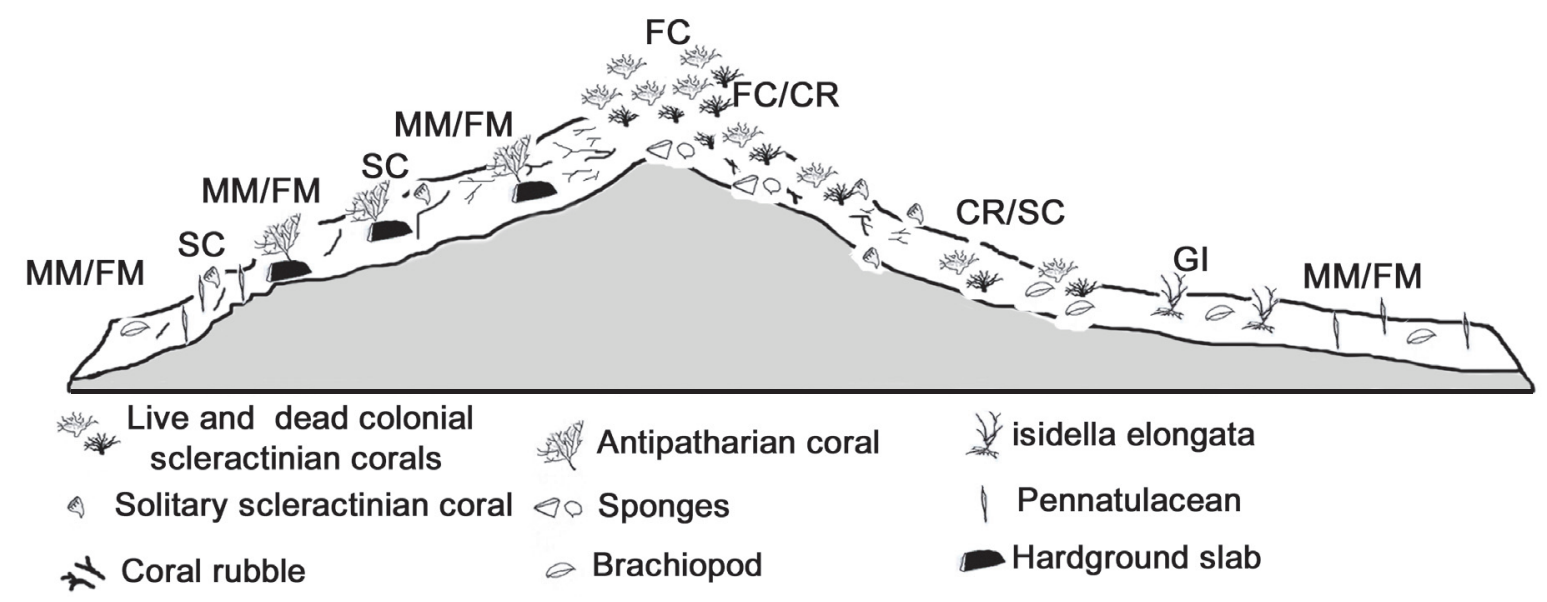

FIGURE 2. Scheme of facies distribution in the Coral mounds (FC=Framework Coral; CR=Coral Rubble; SC=Solitary Corals; GI=Gryphus and Isidella elongata; MM=Mollusc Mud; FM=Foraminifer Mud; see also Table 1; after Rosso et al., 2010, modified).

sible to distinguish two groups of ostracods on the basis of the conservation status of their carapaces. The first group ( $f$ in Appendices 1-3) includes ostracods whose carapaces are fresh-looking and show a rather good preservation state; the second group (w in Appendices 1-3) includes ostracods whose carapaces are opaque and sometimes heavily worn. The most abundant and frequent species are: Bythocypris obtusata and Bairdoppilata conformis, found in 16 and 17 sites, respectively, out of the 20 sampled ones. These species are followed by few other ones, such as Henryhowella ex $\mathrm{H}$. hirta (Costa, 1853) group, found in 12 sites, Macropyxis adriatica (Breman, 1975) found in 10 sites. Among other species Bythocypris bosquetiana (Brady, 1866) and Pseudocythere caudata Sars, 1866 are relatively common and frequent. Finally, a third group is constituted by species rare and poorly preserved, such as Paradoxostoma acuminatum Müller, 1894 and Paracytherois flexuosa (Brady, 1867).

Grouping samples as a function of specimen abundance (Figure 3 ) it is possible to distinguish: a first group, consisting of the samples AP01, AP29 and AP30, in which ostracod associations are abundant ( $>80$ specimens per sample) and diversified (16 species); a second group (samples AP02, AP07, AP08, AP09, AP14t, AP14b, AP15, AP17, AP19b, AP21t, AP22t, AP22b, AP24t) with abundances ranging between 20 and 80 , and moderate species richness (max 8 species) and a third group (samples AP03t, AP03b, AP04, AP05t, AP05b, AP19t, AP21b, AP24b) with no more than 4-5 species and less than 20 specimens per sample, with the exception of sample AP5b, which includes 15 species.

From a comparison between samples, and between the community and the dead assemblages in the same sample (Figure 4), it appears that there is a great variability both in terms of species richness and, mostly, of specimens abundance. Living associations are represented by no more than 5 specimens (samples AP19t and AP22t) whereas dead assemblages vary from a maximum of 229 specimens in the sample AP30 to a minimum of 5 specimens in the sample AP03b.

Looking at facies (Figure 5), it can be observed as ostracod associations are always characterized by a low number of species (with a maximum value of 25) and by a significant number of specimens. Furthermore, these facies (Appendices 1-3) show different species compositions.

The Framework Corals facies (FC) shows a living association only represented by Bithocypris obtusata. The dead assemblage (Appendix 3) consists of 22 species among which Bairdoppilata conformis, Bythocypris obtusata and Paradoxostoma simile Müller,1894 are the best represented, followed by Pseudocythere caudata, Henryhowella ex $H$. hirta group, Argilloecia acuminata Müller, 1894 and Monoceratina mediterranea Sissingh, 1971. 


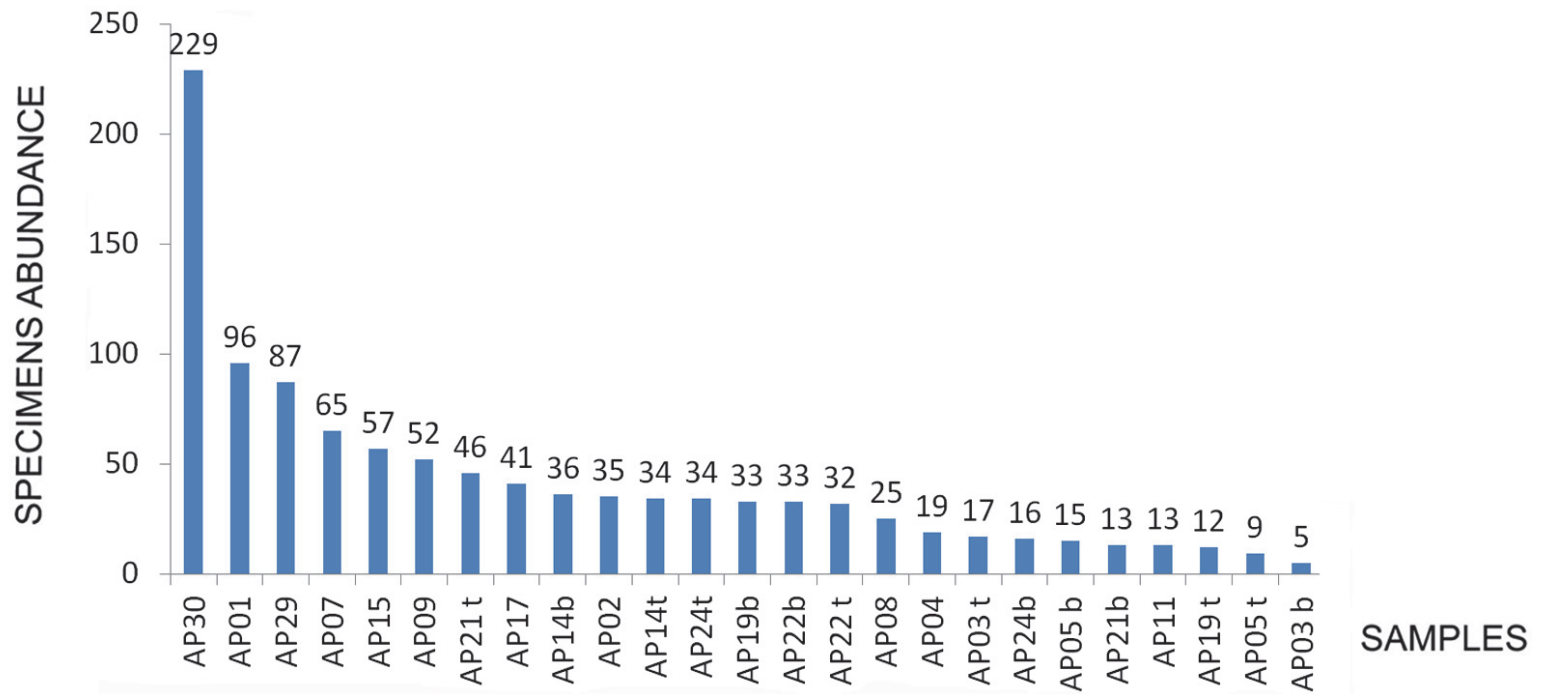

FIGURE 3. Ostracod distribution per samples.

The Coral Rubble facies (CR) includes both species of living ostracods, namely Bairdoppilata conformis and Bythocypris obtusata, while the dead assemblages are formed by only four species, with Henryhowella ex $\mathrm{H}$. hirta group and Macropyxis adriatica, which add to Bairdoppilata conformis and Bythocypris obtusata.

The Solitary Coral/ Hard Ground facies (SC/ HG) consists again of living specimens of Bairdoppilata conformis and Bythocypris obtusata, while the dead assemblages are more diversified than those of the previous facies, including 10 species. $B$. conformis is the dominant species, followed by
B. obtusata, Henryhowella ex $H$. hirta group and Macropyxis adriatica, while Bathycythere vanstraateni Sissingh,1971, Echinocythereis echinata Sars, 1866, Cytheropteron alatum Sars, 1866 and Pterigocythereis jonesii (Baird, 1850) are less represented (Appendix 3). The Gryphus and Isidella facies (GI) include 10 species, and the associations are dominated by $B$. conformis followed by $B$. obtusata and $M$. adriatica.

The same species prevail in the Mollusc Mud (MM) facies where 15 species are present including $B$. conformis, $B$. obtusata and $M$. adriatica.

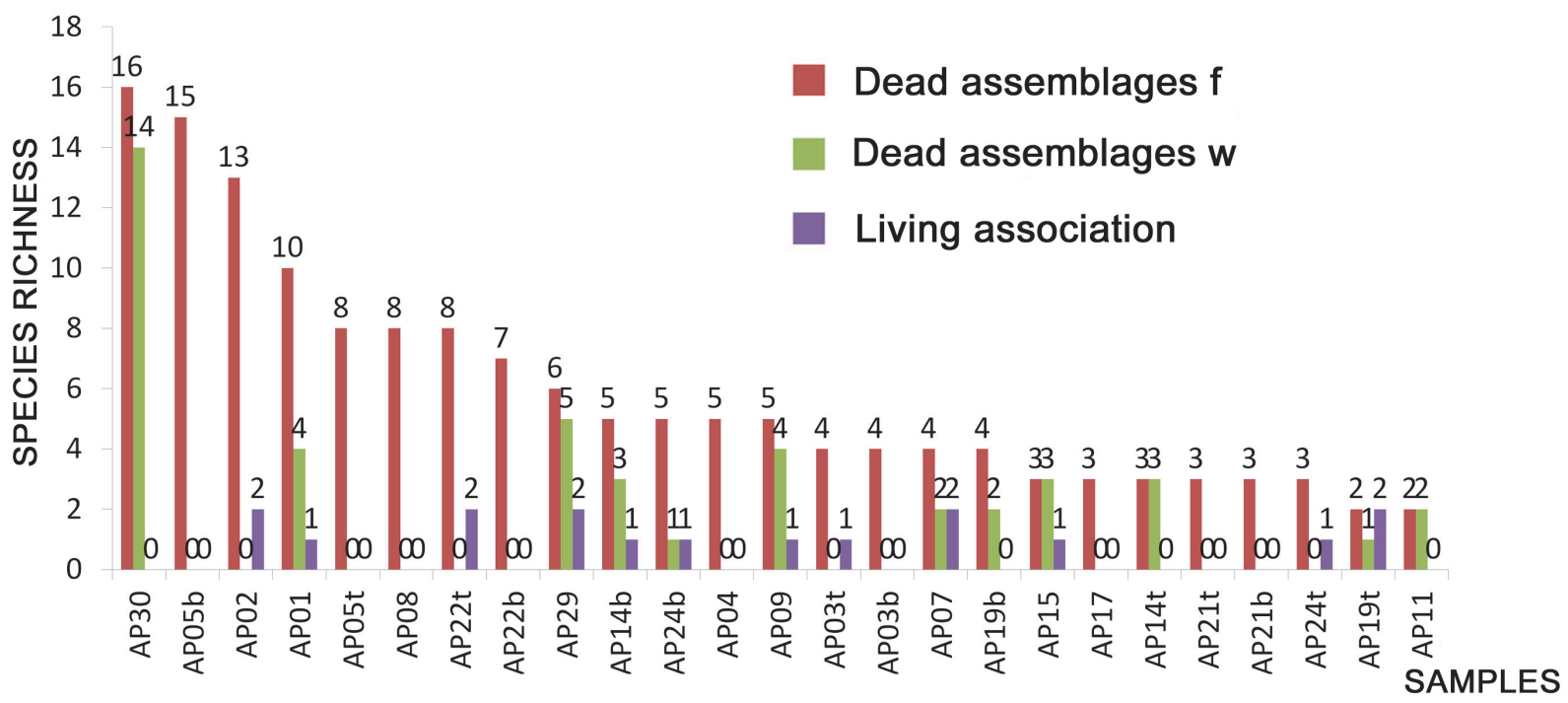

FIGURE 4. Species distribution in dead assemblages "f", dead assemblages "w", and biocoenoses, per sample. 


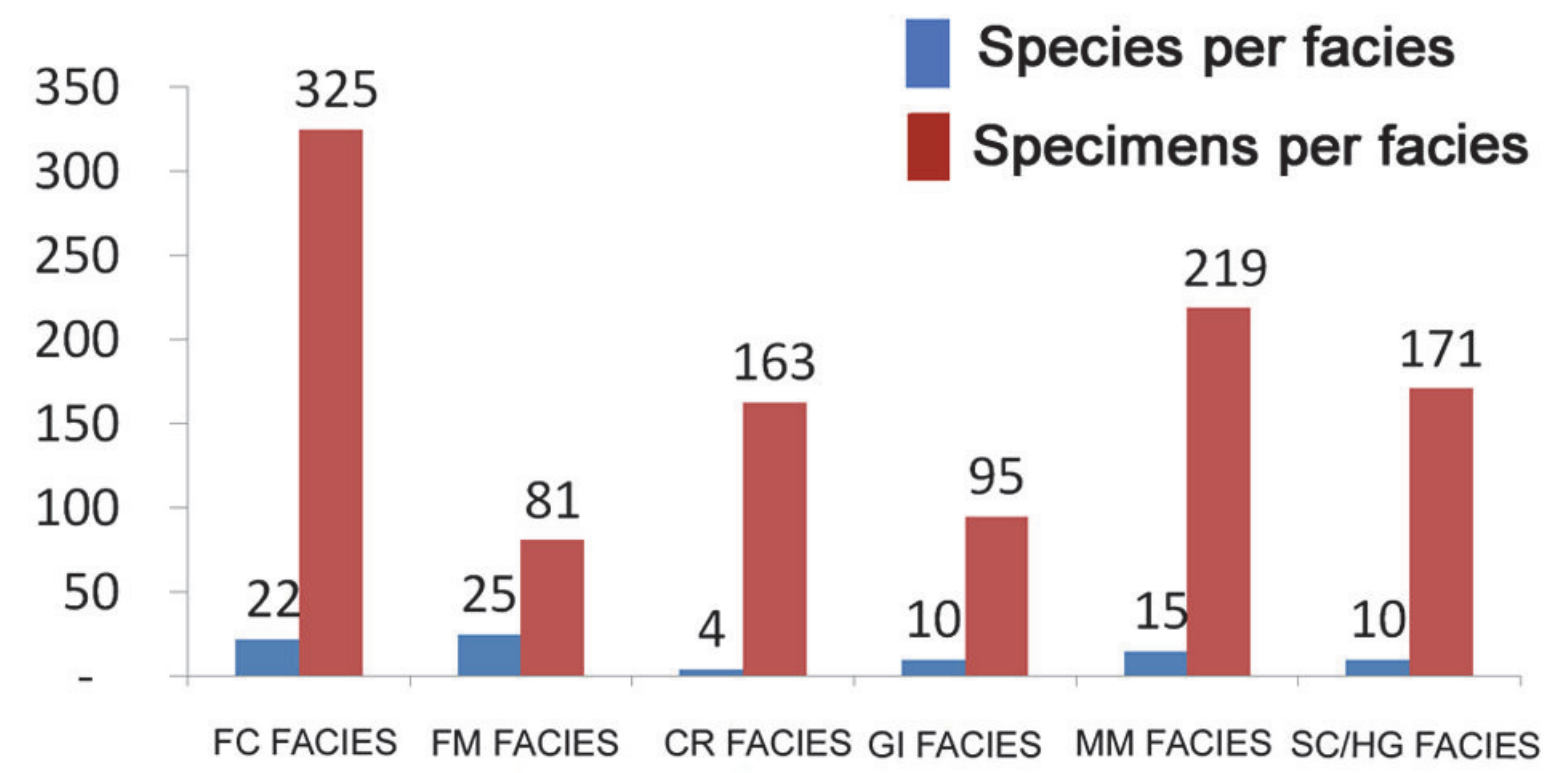

FIGURE 5. Specimens and species abundance per facies. (FC=Framework Coral; $C R=C o r a l$ Rubble; SC/HG=Solitary Coral; GI=Gryphus and Isidella; MM=Mollusc Mud; FM=Foraminifer Mud; see also Table 1).

To conclude, the Foraminifer Mud facies (FM) is the best diversified with a total of 25 species. More than half of these species have been detected only in this facies, although several of them have been found in a single sample and with few specimens. B. conformis, Krithe monosteracensis (Seguenza, 1880) and $H$. ex $H$. hirta group prevail, followed by Argilloecia robusta Bonaduce et al., 1975 and by Buntonia sublatissima (Neviani, 1906).

\section{SYSTEMATICS}

Among all the ostracod species found, some are particularly significant from the systematic and ecologic viewpoint. They are discussed below.

Class OSTRACODA Latreille, 1806

Order PODOCOPIDA Sars, 1866

Family BAIRDIIDAE Sars, 1866

Genus BAIRDOPPILATA Coryell et al., 1935

Type species. Bairdoppilata martyni Coryell et al., 1935

Bairdoppilata conformis (Terquem, 1878)

Figure 6.1

1878 Bairdia subdeltoidea Münster var. conformis Terquem, p. 93, pl. 10, figs. 17 a-c.

1883a Bairdia subdeltoidea Münster; Seguenza, p. 58. 1883b Bairdia subdeltoidea Münster; Seguenza, p. 124, pl. 1, fig. 8.

1975 Bairdia conformis (Terquem); Bonaduce et al., p. 22, pl. 6, figs. 5-10.

1980 Bairdia conformis (Terquem); Colalongo and Pasini, p. 52, pl. 1, fig. 5.

2000 Bairdoppilata conformis (Terquem); Aiello et al., p. 85, pl. 1, fig. 2.

2008 Bairdia conformis (Terquem); Sciuto and Rosso, p. 35, pl. 1, fig. 2.

Remarks. According to Maddocks (1969), the specimens have been referred to the genus Bairdoppilata Coryell et al., 1935 on the basis of the carapace lateral outline, that is rounded and sub hexagonal, and the muscle scar pattern which is shown in Maddocks (1969, figure 3g).

Among the ostracods found in the SML samples, $B$. conformis is by far the most abundant species, one of two found alive. Both adult and juvenile specimens are present. It is particularly abundant in the MM facies, while it is rare in the FM facies.

$B$. conformis shows a present-day very wide bathymetrical distribution that includes the whole Circalittoral and the Bathyal Zone in both the Atlantic Ocean and the Mediterranean Sea (Bonaduce et al., 1983; Whatley and Coles, 1987; Guernet and Lethiers, 1989; Montenegro et al., 1998). 


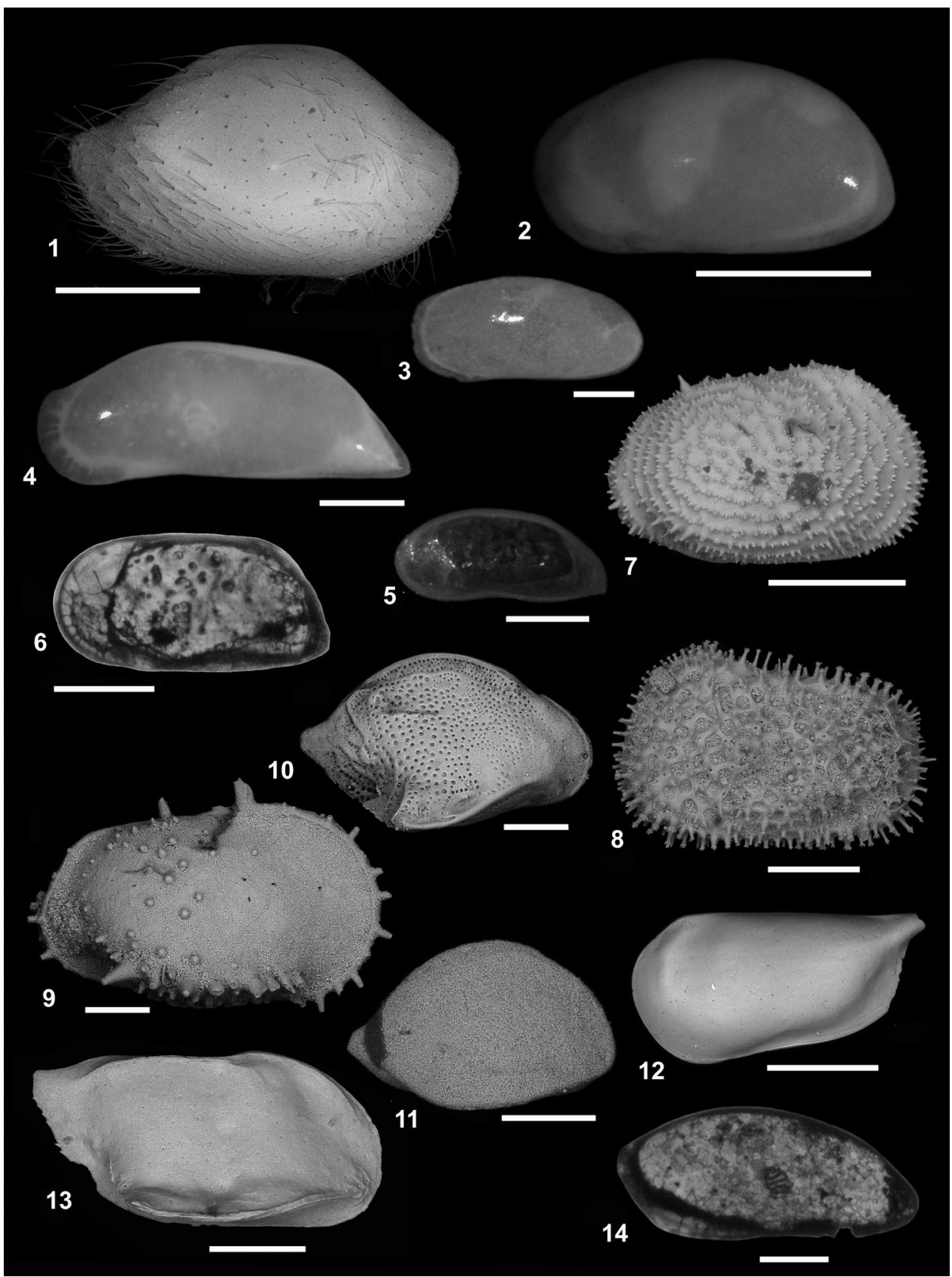

FIGURE 6. 1, Bairdoppilata conformis (Terquem, 1878). PMC. O FS 16. RV, external lateral view (scale bar equals $500 \mu \mathrm{m}$ ); 2, Bythocypris obtusata (Sars, 1866). PMC. O FS 17. LV, external lateral view (scale bar equals $500 \mu \mathrm{m}$ ); 3 , Anchistrocheles tenera (Breman, 1975). PMC. O FS 18. LV, external lateral view (scale bar equals $200 \mu \mathrm{m}$ ); 4, Macropyxis adriatica (Breman, 1975). PMC. O FS 19. LV, external lateral view (scale bar equals $500 \mu \mathrm{m}$ ); 5, Argilloecia acuminata Müller, 1894. PMC. O FS 20. RV, internal lateral view (scale bar equals $100 \mu \mathrm{m}$ ); 6, Krithe monosteracensis (Seguenza, 1880). PMC. O FS 21. RV, internal lateral view (trasparency, scale bar equals $250 \mu \mathrm{m}$ ); 7, Echinocythereis echinata Sars, 1866. PMC. O FS 22. RV, external lateral view (scale bar equals $500 \mu \mathrm{m}$ ); 8, Henryhowella ex H. hirta (Costa, 1853) group. PMC. O FS 23. LV, external lateral view (scale bar equals $200 \mu \mathrm{m}$ ); 9, Bathycythere vanstraateni Sissingh, 1971. PMC. O FS 24. RV, external lateral view (scale bar equals $200 \mu \mathrm{m}$ ); 10, Cytheropteron hadriaricum Bonaduce et al., 1975. PMC. O FS 25. RV, external lateral view (scale bar equals $100 \mu \mathrm{m}$ ); 11, Cytheropteron testudo Sars, 1869. PMC. O FS 26. RV, external lateral view (scale bar equals $200 \mu \mathrm{m}$ ); 12, Pseudocythere caudata Sars, 1866. PMC. O FS 27. LV, external lateral view (scale bar equals $200 \mu \mathrm{m}$ ); 13, Monoceratina mediterranea Sissingh, 1971. PMC. O FS 28. RV, external lateral view (scale equals bar $200 \mu \mathrm{m}$ ); 14, Paradoxostoma simile Müller, 1894. PMC. O FS 29. LV, internal lateral view (trasparency, scale bar equals $200 \mu \mathrm{m}$ ). (PMC. O FS 16-29= Paleontological Museum Catania. Ostracoda Figured Specimens number 16 to 29. RV = right valve; LV = left valve). 
B. conformis has been reported in Plio-Pleistocene sediments deposited in deep environments (Aiello et al., 2000; Sciuto and Rosso, 2008).

Family BYTHOCYPRIDIDAE Maddocks, 1969 Genus ANCHISTROCHELES Brady and Norman, 1889

Type species. Anchistrocheles fumata Brady, 1890

Anchistrocheles tenera (Breman, 1975)

Figure 6.3

1975 Bythocypris tenera Breman, p. 208, pl. 2, figs. 8; pl. 3, fig. 16.

1996 Anchistrocheles tenera (Breman); Aiello et al., p. 272, Text- fig. 1 (f-h).

Remarks. A. tenera is the only species of the genus currently living in the Mediterranean. It has been reported from bathyal environments in western Mediterranean (Bonaduce et al., 1983), including the Gulf of Naples (Aiello et al., 1996). It is also known from the Adriatic Sea, in Pleistocene bathyal sediments referred to cold environments (Breman, 1975).

In the SML CWCP it is present only in the Mollusc Mud facies (MM) and in the Gryphus and Isidella facies (IGI).

Genus BYTHOCYPRIS Brady, 1880

Type species. Bythocypris reniformis Brady, 1880

Bythocypris bosquetiana (Brady, 1866)

1866 Bairdia bosquetiana Brady; p. 364, p. 57, fig. 5.

1880 Cytheridea lucida Seguenza; p. 290, pl. 16, figs. 51, 51a.

1894 Bythocypris bosquetiana (Brady); Müller, p. 275, pl. 14, figs.16-18, 20, 31.

1900 Bythocypris bosquetiana (Brady); Namias, p. 88, pl. 14, fig. 8.

1964 Bythocypris lucida (Seguenza); Ascoli, p. 218, pl. 4, fig. 3.

1972 Bythocypris bosquetiana (Brady); Sissingh, p. 78 , pl. 3, fig. 7 .

1979 Bythocypris bosquetiana (Brady); Yassini, p. 375.

1980 Bythocypris lucida (Seguenza); Colalongo and Pasini, p. 52, pl. 2, fig. 7, 8.

2000 Bythocypris bosquetiana (Brady); Aiello et al., p. 88, pl. 1, fig. 10, pl. 6, fig. 2 .

2008 Bythocypris bosquetiana (Brady); Sciuto and Rosso, p. 35, pl. 1, fig. 4.
Remarks. $B$. bosquetiana is rare in the SML samples, and it has been found only in the CF and FM facies dead assemblages. In the Recent AtlanticMediterranean region this species occurs in the depth range 150-3381 $\mathrm{m}$ (Aiello et al., 2000) and as fossil it has been found in sediments referable to deep environments (Sciuto, 2003, 2005; Sciuto and Rosso, 2008).

Bythocypris obtusata (Sars, 1866)

Figure 6.2

1866 Bairdia obtusata Sars, p. 24.

1880 Bairdia obtusata Sars var. producta, Seguenza, p. 191.

1880 Cytheridea lucida Seguenza, p. 290, pl. 16, fig. 51.

1987 Bythocypris lucida (Seguenza); Aranki, p. 48, pl. 2, fig. 6.

1972 Bythocypris obtusata (Sars); Sissingh, p. 79, pl. 3, figs. 10, 11.

1972 Bythocypris lucida (Seguenza); Sissingh, p. 78, pl. 3, figs. 8, 9 .

1975 Bairdia obtusata Sars; Breman, p. 205, pl. 2, fig. 9.

1980 Bythocypris obtusata (Sars); Colalongo and Pasini, p. 52, pl. 2, figs. 9, 10.

1981 Bythocypris obtusata (Sars); Tsapralis, p. 83, pl. 4, figs. 1-3.

2008 Bythocypris obtusata (Sars); Sciuto and Rosso, p. 35, pl. 1, fig. 3.

Remarks. The species is widespread in the SML samples. It is one of two species found alive. $B$. obtusata is currently reported at $300 \mathrm{~m} \mathrm{WD}$ in the Gulf of Naples (Bonaduce and Pugliese, 1979), between 600 and $2669 \mathrm{~m}$ WD in the Atlantic-Mediterranean Region (Bonaduce et al., 1983), at 145$165 \mathrm{~m}$ water depth along the Norwegian and British coasts (Sars, 1928) and in the Recent Mediterranean Sea between 150 and $2905 \mathrm{~m}$ (Puri et al., 1964). Also the fossil record of this species points to bathyal palaeoenvironments (Tyrrhenian Sea: Colalongo et al., 1988, 1990; Le Castella: Colalongo, 1965; Capo Milazzo: Sciuto, 2003, 2005; Furnari: Sciuto and Rosso, 2008; Vrica: Colalongo and Pasini, 1980).

Family BYTHOCYTHERIDAE Sars, 1866 Genus BYTHOCYTHERE Sars, 1866

Type species. Bythocythere turgida Sars, 1866 Bythocythere mylaensis Sciuto, 2009

2005 Bythocythere sp. 1. Sciuto, p. 222. 
2009 Bythocythere mylaensis, Sciuto, pl. 1, figs. 112.

Remarks. This species was found only in the Framework Corals facies (CF). B. mylaensis can be considered as a bathyal taxon because it is always found in typically deep water associations, with ecological requirements seemingly unchanged throughout the Pleistocene. Presently, $B$. mylaensis seems to have restricted both stratigraphical and geographical distributions, known only from Pleistocene sediments of the central Mediterranean area, including north-eastern Sicily (Lower Pleistocene outcrops) and the northern Ionian Sea (Upper Pleistocene underwater cores).

Genus PSEUDOCYTHERE Sars, 1866

Type species. Pseudocythere caudata Sars, 1866

Pseudocythere caudata Sars, 1866

Figure 6.12

1894 Pseudocythere caudata Sars; Müller, p. 284, pl. 16, figs. 5, 10.

1980 Pseudocythere caudata Sars; Colalongo and Pasini, p. 64, pl. 26, fig. 5.

1992 Pseudocythere caudata Sars; Ciampo, p. 227.

2005 Pseudocythere caudata Sars; Sciuto, p. 222.

2014 Pseudocythere caudata Sars; Sciuto, p. 4.

2014 Pseudocythere caudata Sars; Yasuhara and Okahashi, p. 774, figs. 2.9, 2.10.

2014 Pseudocythere caudata Sars; Yasuhara et al., p. 348, figs. 5.1, 5.2.

Remarks. The subspecies Pseudocythere caudata mediterranea Bonaduce et al., 1980 was created on the basis of slight differences in the soft part and in the carapace. The SML specimens do not show these features. They were, therefore, attributed to the Sars species.

$P$. caudata was found mostly in the Framework Corals facies (CF). In the Recent Mediterranean, this species seems to have a very wide ecological distribution from shallow continental shelf to abyssal environments. However, it is known throughout the Pliocene and the Pleistocene always from sediments presumably deposited in deep water environments. In the Pleistocene sediments of Scoppo (ME) several complete specimens of $P$. caudata were found in proximity of coral rudstones (Sciuto, unpublished data), in environmental condition, which may be considered very similar to those currently found at SML.

Such an abundance of $P$. caudata specimens in deep environments might be explained with the abundance of food due to the presence of coral colonies, as suggested for species belonging to Paradoxostoma, Paracytherois and Sclerochilus (Coles et al., 1996).

Family CYTHERURIDAE Müller, 1894

Genus CYTHEROPTERON Sars, 1866

Type species. Cythere latissima Norman, 1865

Cytheropteron testudo Sars, 1869

Figure 6.11

1869 Cytheropteron testudo Sars, p.173, pl. 173, fig. 1.

1889 Cytheropteron testudo Sars; Brady and Norman, p. 219, pl. 21, figs. 1, 2.

1985 Cytheropteron testudo Sars; MontcharmontZei et al., p. 30, pl. 1, fig. 6.

1999 Cytheropteron testudo Sars; Swanson and Ayress, p. 157, pl. 4, figs. 1-12, pl. 5, figs.1-13, pl. 6, figs. 10-12.

2003 Cytheropteron testudo Sars; Stepanova et al., p. 31, pl. 11, figs. 5, 6 .

2011 Cytheropteron testudo Sars; Faranda and Gliozzi, p. 82, fig. 12.

2012 Cytheropteron testudo Sars; Sciuto, p. 122, fig. 3a.

Remarks. C. testudo Sars, 1869 is presently restricted to the area between the Norwegian coasts and the Arctic bioprovince. Consequently, it is considered as one of the northern guests widespread in the Mediterranean during the Quaternary (Faranda and Gliozzi, 2011). This species has been found in western Laptev Sea, at $68 \mathrm{~m}$ water depth by Stepanova et al. (2003); along the Norwegian coast, at depths of 80 to $240 \mathrm{~m}$, and in the Recent Atlantic, between 1380 and 3526 m water depth by Dingle and Lord (1990); in the Queensland Plateau (SW Pacific) in Holocene to Recent sediments deeper than $500 \mathrm{~m}$ by Swanson and Ayress (1999). As fossils, the species has been reported from the Early Pliocene to the Quaternary from bathyal sediments of the Atlantic Ocean (Whatley and Coles, 1987) and from to Early Pleistocene in bathyal sediments of the Mount S. Nicola section (Aiello et al., 2000). In the Mediterranean Sea its last occurrence corresponds to the Last Glacial (Montcharmont-Zei et al., 1985). Therefore $C$. testudo could be considered as a stenothermic species restricted to very cold waters independently of depth.

This species was found only in the Framework Corals facies (CF). 
Family MACROCYPRIDIDAE Müller, 1912

Genus MACROPYXIS Maddocks, 1990

Type species. Macropyxis sapeloensis Darby, 1965

Macropyxis adriatica (Breman, 1975)

Figure 6.4

1975 Macrocypris adriatica Breman, p. 210, pl. 2, figs. 6 a-c, pl. 4, figs. 17 a-d.

1980 Macrocypris ligustica Bonaduce et al.; Colalongo and Pasini, p. 62, pl. 23, fig. 7.

1985 Macrocypris adriatica Breman; Moncharmontn-Zei et al., pl. 1, fig. 2.

1990 Macropyxis adriatica (Breman); Maddocks, p. 60 , figs. $8(9,10), 9(9,10), 19(10), 22$ (20), 24 (6), 16 (9-12), 17(9-12), 78 (30).

2010 Macrocypris adriatica Masoli (sic!); Rosso et al., p. 365 , fig. 11, I.

Remarks. This species has been found in all the facies identified in the sampled area but it is not abundant (Table 1, Figure 2). M. adriatica has been reported from the Pleistocene of the Mediterranean and Aegean areas but it seems to be extinct in the Recent Mediterranean. Interestingly, Breman (1975) found $M$. adriatica in levels dated to the Upper Pleistocene including the Allerød and Younger Dryas climatic stage (cores 353 in the Adriatic Sea), and considered this species as a cold water indicator.

Family TRACHILEBERIDAE Sylvester-Bradley, 1948

Genus BATHYCYTHERE Sissingh, 1971

Type species. Bathycythere vanstraateni Sissingh, 1971

Bathycythere vanstraateni Sissingh, 1971

Figure 6.9

1971 Bathycythere vanstraateni Sissingh, p. 410, pl. 1, 2, figs. 2-4.

1971 Xandarosina n. nudum, Benson and Sylvester-Bradley, p. 68, figs. 3 a, b.

1975 Bathycythere vanstraateni Sissingh; Breman, p. 213, pl. 4, fig. 20.

1980 Bathycythere vanstraateni Sissingh; Colalongo and Pasini, p. 52, plate 4, figs. 7, 8.

1983 Bathycythere vanstraateni Sissingh; Bonaduce et al., p. 463.

1985 Bathycythere vanstraateni Sissingh; Montcharmont-Zei et al., pl. 1, fig. 7.

1988 Bathycythere vanstraateni Sissingh; Colalongo and Pasini, p. 283.
1988 Bathycythere vanstraateni Sissing; van Harten and Droste, p. 732, pl. 1, fig. 1.

1990 Bathycythere vanstraateni Sissingh; Colalongo et al., p. 483.

1997 Bathycythere vanstraateni Sissingh; Pasini and Colalongo, p. 18.

2004 Bathycythere vanstraateni Sissingh; Mazzini, p. 48 , figs. $25 \mathrm{~K}-\mathrm{N}$.

Remarks. This species is poorly represented in the $\mathrm{SML}$ area and is restricted to the Framework Coral facies (FC) and the Hardground fragments colonized by the Solitary Coral facies (SC).

$B$. vanstraateni is listed among the abyssal ostracods living in the Atlantic Ocean, and Pasini and Colalongo (1997) considered it as a psychrospheric species. It seems to be extinct in the Recent Mediterranean, from where it has been recorded from depths shallower than the SML ones (van Harten, 1990).

Breman (1975) found this species in sediments from the Adriatic Sea dated to the basal Holocene including the Allerød and the Younger Dryas climatic stages. van Harten and Droste (1988) stated that this species disappeared from the eastern Mediterranean about $9 \mathrm{Ka}$ ago together with $K$. monosteracensis and $M$. adriatica, following an anoxic event related to sapropel deposition. A comparable distribution can be desumed from Colalongo et al. (1990, figure 3 ) for cores from the Tyrrhenian Sea.

Genus BUNTONIA Howe, 1935 in Howe and Chambers, 1935

Type species. Buntonia shubutaensis Howe, 1935 in Howe and Chambers, 1935

Buntonia sublatissima (Neviani, 1906)

1906 Cythere sublatissima Neviani, p. 198, fig. 8.

1954 Buntonia sublatissima (Neviani); Ruggieri, p. 564, figs. 22, 24, 27, 29, 31.

1960 Buntonia sublatissima sublatissima (Neviani); Medioli, p. 215, text- fig. 1.

1964 Buntonia sublatissima (Neviani); Puri et al. p. 118, fig. 23.

1972 Buntonia (Buntonia) sublatissima sublatissima (Neviani); Sissingh, p. 95, pl. 6, fig. 7.

1975 Buntonia sublatissima (Neviani); Bonaduce et al., p. 55, pl. 33, figs. 6-11.

1979 Buntonia sublatissima (Neviani); Yassini, p. 106, pl. 2, figs. 16, 23, 24.

1984 Buntonia sublatissima (Neviani); Malz and Jellinek, p. 124, pl. 1, fig. 2. 
1993 Buntonia sublatissima (Neviani); Nachite et al., p. 33, pl. 4, fig. 11.

2000 Buntonia sublatissima (Neviani); Ruiz et al., p. 237.

2000 Buntonia sublatissima (Neviani); Aiello et al., p. 98, pl. 4, fig. 10.

2008 Buntonia sublatissima (Neviani); Ruiz et al., p. 850.

Remarks. This species is present only in the Foraminifer Mud facies (FM) with few specimens.

$B$. sublatissima is known from the Upper Miocene (Carbonel, 1985) to nowadays (Ruiz et al., 2000). In the Mediterranean Sea its presence seems to be restricted to the continental shelf (Puri et al., 1964; Bonaduce et al., 1976, 1988).

\section{Genus ECHINOCYTHEREIS Puri, 1954}

Type species. Cythereis garretti Howe and Mc Guirt, 1935 in Howe and graduate students, 1935

Echinocythereis echinata (Sars, 1866)

Figure 6.7

1866 Cythere echinata Sars, p. 44.

1975 Echinocythereis echinata (Sars); Breman, p.213, pl. 4 fig. 21.

1983 Echinocythereis echinata (Sars); Bonaduce et al., pl. 3, Figure 4.

1984 Echinocythereis echinata (Sars); Peypouchet and Nachite, pl. 2, figs. 3, 4.

1985 Echinocythereis sp.1; Moncharmont-Zei et al., pl. 1, fig. 10.

1990 Echinocythereis echinata (Sars); van Harten, p. 325, fig. 21.

1990 Echinocythereis echinata (Sars); Dingle and Lord, p. 225, fig. 2.3.

2009 Echinocythereis echinata (Sars); AlvarezZarikian, p. 6, pl. 9, figs. 3, 4.

2014 Echinocythereis echinata (Sars); Yasuhara et al., p. 354, fig. 7.5 .

2014 Echinocythereis echinata (Sars); Yasuhara and Okahashi, p. 782, fig. 8.2.

Remarks. This species has been detected in almost all the facies sampled in the SML CWC. E. echinata seems to be absent from the Recent Mediterranean but it has been reported from layers deposited during the cold phases of the Pleistocene (Breman, 1975; Peypouchet and Nachite, 1984; Moncharmont-Zei et al., 1985). According to Barra and Bonaduce (2000), this species can be considered as a cold water indicator.
Genus HENRYHOWELLA Puri, 1957

Type species. Henryhowella evax Ulrich and Bassler, 1904

Henryhowella ex H. hirta (Costa, 1853) group Figure 6.8

1853 Cypridina hirta Costa, p. 174, pl. 15, figs. 2 a, c.

1894 Cythereis sarsii Müller, p. 370, pl. 8, fig. 8.

1950 Cythereis hirta (Costa); Ruggieri, p. 25.

1980 Henryhowella asperrima (Reuss); Yassini, p. 102, pl. 6, figs. 6, 8, 10.

1999 Henryhowella sarsii sarsii (Müller); Bonaduce et al., p. 64, pl. 2, figs. 1-10, pl. 3, fig. 12, pl. 4, figs. 9, 10, pl. 5, figs. 1, 2, 6, 8, 11.

1999 Henryhowella parthenopea Bonaduce et al., p. 61 , pl. 3 , figs. $1-11,13,14$, pl. 4 , figs. 11 , 12, pl. 5, figs. 3-5, 9, 10, 12.

2003 Henryhowella hirta (Costa); Guernet et al., p. 84.

2008 Henryhowella parthenopea Bonaduce et al.; Faranda and Gliozzi, pl. 6, figs. 2, 5, 8, 11.

2014 Henryhowella ex H. hirta (Costa, 1853) group; Sciuto, p. 6, pl. 1.H.

Remarks. Following Sciuto (2014), some specimens have been ascribed to Henryhowella ex $\mathrm{H}$. hirta (Costa, 1853) group, which is present in nearly all the facies in the studied area.

\section{DISCUSSION AND CONCLUSION}

The ostracod fauna found in the SML CWC province consists of 42 taxa. Only two species, Bairdoppilata conformis and Bythocypris obtusata, were found alive in nearly all the facies detected. Both of them are already known as common in deep-water environments. Looking at dead assemblages, most of the ostracod species detected can be considered as in equilibrium with present-day bathymetry at each site. Consequently they are mostly considered as preserved in situ. Noteworthy, several taxa can be considered as stenothermic and rather ecologically restricted to cold waters independently from depth. This is the case for Cytheropteron testudo, and probably for B. obtusata, Macropyxis adriatica and Echinocythereis echinata (Breman, 1975; Sciuto, 2009). Further species, such as Bathycythere vanstraateni (Breman, 1975) and Bythocythere mylaensis (Sciuto, 2009), are typical of bathyal environments or have wide bathymetric distributions, which include preferentially the bathyal zone, such as Pseudocythere caudata, Bythocypris bosquetiana, Henryhowella 
ex H. hirta group and Cytherella vulgatella (Montenegro et al., 1998).

Significantly, the composition of the ostracod fauna from SML shows some similarities with those found in the core 353 located at $1200 \mathrm{~m} \mathrm{WD}$ in the southern Adriatic Basin (Breman, 1975) as well as in cores from the Gulf of Taranto (MontcharmontZei et al., 1985). Compositional similarity is particularly evident for levels A and B of the 353 core, dated to the Upper Pleistocene, also including the climatic stages Allerød and Younger Dryas. In the Gulf of Taranto, levels which delivered Cytheropteron testudo, Macropyxix adriatica and Bathycythere vanstraateni were attributed to a cold period, at the end of the last glaciation. The disappearance of $M$. adriatica, $B$. vanstraateni and Krithe monosteracensis has been documented in the Eastern Mediterranean Basin at the base of the early Holocene in correspondence to the sapropel S1 deposited approximately between 9000 and 7000 YBP (van Harten and Droste, 1988). Therefore, data collected so far seems to confirm that the ostracod fauna of SML CWC province also include species no longer found in the Recent Mediterranean Sea, but they partly document an association which lived during a cold phase of the Late Pleistocene (Allerød) or during the transition to the Holocene (Younger Dryas) when low temperatures still allowed their presence in this area, approximately between 11.800 and 10.000 YBP (sensu Hoek, 2008). These species, particularly C. testudo and Bythocythere mylaensis, include opaque, sometimes heavily worn carapaces, and have been reported in the columns "W" in Appendices 1 and 2.

Some scarce species belonging to Callistocythere, Loxoconcha, Neocytherideis and Cytheridea, typical of shallow water shelf habitat, were considered as displaced. The fauna displacement phenomenon, indeed, may be due to frequent downslope mass movement due to the steep morphology of the seafloor and the intense tectonic activity in the area (Savini and Corselli, 2010).

Interestingly, some species, such as Paradoxostoma simile, Paradoxostoma acuminatum and Paracytherois flexuosa, have been found mainly in the Framework Corals facies (CF) usually with a high number of specimens. Their presence could be related to the existence of favourable environmental parameters in this habitat. The abovementioned taxa have been reported especially from shelf environments rich in plants and/or biodetritus (e.g., Whatley and Wall, 1975; Athersuch et al., 1989; Coles et al., 1996), as well as from deep bio- topes. On the basis of current knowledge, despite the scarcity of autoecological data and some concerns about taxonomical determinations, already remarked by Maddocks and Steineck (1987) and Athersuch et al. (1989), it is presumable that the extension of their distribution to deep environments is related to favourable trophic conditions, as suggested for comparable environments by Passlow (1997). This has been proven by Maddocks and Steineck (1987) who report the discovery of a living specimen, probably referable to the species Schlerochilus contortus, at $1830 \mathrm{~m}$ water depth on artificial wood panels anchored to the bottom of the Caribbean Sea. These panels formed "wood islands", where a significant increase of food resources potentially exploitable by ostracods (film of bacteria and fungi, mucus secreted by echinoderms, fecal pellets, decaying tissues) was observed. The ostracod populations are characterized by the simultaneous presence of purely xilophilous ostracods, as well as by epiphytic or scavenging taxa, or by parasites on other organisms, all typical of shallow environments, usually as abundant as those typical of the bathyal environments.

A considerable availability of trophic resources exploitable by bathyal ostracods as well as by associated typical "shallow marine, phytal taxa", such as Paradoxostoma, Paracytherois and Sclerochilus species, has been reported by Coles et al. (1996) from bathyal coral bioconstructions from the Porcupine Basin at $750 \mathrm{~m}$ water depth. It is worth noting that in the SML CWC province, as well as in the Porcupin Basin, the abundance of these taxa rises to a maximum in the Framework corals facies and progressively lowers moving away from areas colonized by corals, possibly in relation to a decrease of available resources. Therefore, the presence of abundant trophic resources may have caused the extension toward deeper areas of taxa, such as Paradoxostoma and Paracytherois. Species of such genera can be interpreted as in situ rather than displaced from shallow environments, as already noted in North Atlantic Holocene bathyal associations by Coles et al. (1996).

\section{ACKNOWLEDGEMENTS}

The authors are grateful to the anonymous referees for the suggestions on the manuscript. Special thanks are due also to the crew of the research vessel Universitatis and to Mr. Alfio Viola (University of Catania) for SEM assistance. Palaeoecological Research Group contribution n. 399. 


\section{REFERENCES}

Aiello, G., Barra, D., and Bonaduce G. 1996. Anchistrocheles interrupta a new deep-water marine ostracod species (Pusselinae, Ostracoda) from the Plio-Pleistocene of the Mediterranean Basin. Bollettino della Società Paleontologica Italiana, 34:271-274.

Aiello, G., Barra, D., and Bonaduce, G. 2000. Systematics and biostratigraphy of the ostracoda of the PlioPleistocene Monte S. Nicola section (Gela, Sicily). Bollettino della Società Paleontologica Italiana, 39:83-112.

Aiello, G., Barra, D., Bonaduce, G., and Russo, A. 1996. The genus Cytherella Jones, 1849 (Ostracoda) in the Italian Tortonian-Recent.Revue de Micropaléontologie, 39:171-190

Alvarez-Zarikian, C. A. 2009. Data report: Late Quaternary ostracodes at IODP site U1314 (North Atlantic Ocean), p. 1-22. In Channel, J.E.T., Kanamatsu, T., Sato T., Stein R., Alvarez Zarikian, C.A., Malone, M.J., and the expedition 303/306 Scientists (eds.), Proceedings of the Integrated Ocean Drilling Program. Texas A\&M University, College Station, TX.

Aranki, J.F. 1987. Marine lower Pliocene Ostracoda of southern Spain with notes on the recent fauna. Bulletin of the Geological institutions of the University of Uppsala N. S., 13:1-94.

Ascoli, P. 1964. Preliminary ecological study on Ostracoda from bottom cores of Adriatic Sea. Pubblicazioni della Stazione Zoologica di Napoli, 33(Suppl.):213-246.

Athersuch, J., Horne, D.J., and Whittaker, J.E. 1989. Marine and brackish water ostracods, p.1-343. In Kermack, D.M. and Barnes, R.S.K. (eds.), Synopses of the British Fauna. The Linnean Society of London, London.

Auroux, C., Mascle, J., Campredon, R., Mascle, G., and Rossi, S. 1985. Cadre géodynamique et évolution récente de la Dorsale Apulienne et de ses bordures. Giornale di Geologia, serie 3, 47(1,2):101-127.

Baird, W. 1850. The Natural History of the British Entomostraca. Ray Society, London.

Barra, D. and Bonaduce, G. 2000. Some species of Echinocythereis Puri, 1954 (Crustacea, Ostracoda) from Tortonian to Recent. Revista Española de Micropaleontologia, 32:213-224.

Benson, R.H. and Sylvester-Bradley, P.C. 1971. Deepsea ostracodes and the transformation of ocean to sea in the Tethys, p. 63-91. In Oertli, H.J. (ed.), Paléoécologie des ostracodes. Bulletin du Centre de Recherches, 5 suppl. S.N.P.A., Pau.

Bonaduce, G., Barra, D., and Aiello, G. 1999. The genus Henryhowella Puri, 1957 (Crustacea, Ostracoda) in the Atlantic and Mediterranean from Miocene to Recent. Bollettino della Società Paleontologica Italiana, 38:59-72.

Bonaduce, G., Ciampo, G., and Masoli, M. 1975. Distribution of Ostracoda in the Adriatic Sea. Pubblicazioni della Stazione Zoologica di Napoli, 40(Suppl.):1-304.
Bonaduce, G., Ciliberto, B., Masoli, M., Minichelli, G., and Pugliese, N. 1983. The deep-water benthic ostracodes of the Mediterranean, p. 459-471. In Maddocks, R.F. (ed.), Application of Ostracoda. Department of Geosciences, University of Houston, Houston.

Bonaduce, G., Masoli, M., Pugliese, N., and Mc Kenzie, K. 1980. The genus Pseudocythere Sars (Crustacea, Ostracoda) in the Bay of Naples. Bollettino della Società Paleontologica Italiana, 19:136-142.

Bonaduce, G. and Pugliese, N. 1979. Benthic ostracods as depth indicators. Rapports de la Commision International sur la Mer Méditerranée, 25/26:167-169.

Born, I. 1778. Index rerum naturalium Musei Caesarei Vindobonensis. Verzeichniss der Natürlichen Seltenheiten des K.K. Naturalien Kabinets zu Wien. Erster Theil, Schalthiere. Vindobonae. https://archive.org/ details/indexrerumnatura00born

Brady, G.S. 1866. On new or imperfectly known species of marine Ostracoda. Transaction of the Zoological Society of London, 5:956-393.

Brady, G.S. 1867. Report on the Ostracoda dredged amongst the Hebrides. Report of the British Association for the Advancemet of Science. 36th meeting 1866:208-211.

Brady, G.S. 1880. Report on the Ostracoda dredged by H.M.S. Challenger during the years 1873-1876. Report on the scientific results of the voyage of H.M.S. Challenger during the years 1873-1876. Zoology, 1:1-184.

Brady, G.S. 1890. On Ostracoda collected by H.B. Brady in the South Sea islands. Transactions of the Royal Society of Edinburgh, 35:489-525.

Brady, G.S., Crosskey, H.W., and Robertson, D. 1874. A monograph of the post-tertiary Entomostraca of Scotland, including species from England and Ireland. Monograph of the Palaeontographical Society, 28:1274.

Brady, G.S. and Norman, A.M. 1889. A monograph of the marine and freshwater Ostracoda of the North Atlantic and of the Northwestern Europe. Section I Podocopa. Scientific Transactions of the Royal Dublin Society, Ser. 2, 4:63-270.

Breman, E. 1975. Ostracodes in a bottom core from the deep southeastern basin of the Adriatic Sea. I, II. Koninklijke Nederlandse Akademie van Wetenschappen, Proceding, Ser. B, 78:198-218.

Carbonel, P. 1985. Néogène, p. 313-335. In Oertly, H.J. (ed.), Atlas des Ostracodes de France. Bulletin du Centre Recherche Elf Exploration Production, Pau.

Ciampo, G. 1992. Ostracofaune plioceniche della Calabria ionica. Bollettino della Società Paleontologica Italiana, 31:223-239.

Colalongo, M.L. 1965. Gli Ostracodi della serie di Le Castella (Calabria). Giornale di Geologia, 33:83-123.

Colalongo, M.L. and Pasini, G. 1980. La ostracofauna Plio-Pleistocenica della sezione della Vrica in Calabria (con considerazioni sul limite Neogene-Quaternario). Bollettino della Società Paleontologica Italiana, 19:44-126. 
Colalongo, M.L. and Pasini, G. 1988. Ostracofauna pliopleistocenica batiale rinvenuta nel Pozzo 654A dell'ODP Leg 107 (Mar Tirreno occidentale). Bollettino della Società Paleontologica Italiana, 27:277289.

Colalongo, M.L., Pasini, G., Poluzzi, A., and Sprovieri, R. 1990. Relationship between the benthic foraminifers and the ostracodes in the Pliocene-Pleistocene Tyrrhenian deep-sea record (ODP LEG 107, site 654). Proceedings of the Ocean Drilling Program, Scientific Results, 107:479-493.

Coles, G.P., Ainsworth, N.R., Whatley, R.C., and Jones, R.W. 1996. Foraminifera and Ostracoda from Quaternary carbonate mounds associated with gas seepage in the Porcupine Basin, offshore Western Ireland. Revista española de Micropaleontologia, 28:113-151.

Corselli, C. 2010. The Aplabes programme. Physical, Chemical and Biological Characterization of deepwater coral ecosystem from the Ionian Sea (Mediterranean). Deep-Sea Research, Part II, Topical Studies in Oceanography, 5:323-492.

Coryell, H.N, Sample, C.H., and Jennings, P.H. 1935. Bairdoppilata, a New Genus of Ostracoda, with Two New Species. American Museum Novitates, 777:1-5.

Costa, O.G. 1853. Paleontologia del Regno di Napoli. Atti Accademia Pontoniana, 3. Napoli.

Darby, D.G. 1965. Ecology and taxonomy of Ostracoda in the vicinity of Sapelo Island, Georgia, p. 57-136. In Kesling, R.V., Darby, D.G., Smith, R.N., and Hall, D.D. (eds.), Four reports of ostracod investigations conducted under National Science Foundation Project GB-26. Univ. Michigan, Museum Paleontology, Michigan.

Dingle, R.V. and Lord, A.R. 1990. Benthic ostracods and deep water-masses in the Atlantic Ocean. Palaeogeography, Palaeoclimatology, Palaeoecology, 80:213235.

Esper, E.C.J. 1788. Die Pflanzenthiere in Abbildungen nach der Natur mit Farben erleuchtet, nebst Beschreibungen. Zweyter Theil, Raspe, Nürnberg.

Faranda, C. and Gliozzi, E. 2008. The ostracod fauna of the Plio-Pleistocene Monte Mario succession (Roma, Italy). Bollettino della Società Paleontologica Italiana, 47:215-267.

Faranda, C. and Gliozzi, E. 2011. A revision of the "northern guest" Ostracoda (Crustacea) occurrence in the Quaternary of the Mediterranean area. // Quaternario, 2:75-92.

Guernet, C., Lemeille, F., Sorel, D., Bourdillon, C., Berge-Thierry, C., and Manakou, M. 2003. Les Ostracodes et le Quaternaire d'Aigion (Golfe de Corinthe, Grèce). Revue de Micropaléontologie, 46:73-93.

Guernet, C. and Lethiers, F. 1989. Ostracodes et recherche des milieux anciens: possibilités et limites. Bulletin de la Société Géologique de France, 8:577-588.
Hoek, W.Z. 2008. The last Glacial - Interglacial Transition. Episodes, 31:226-229.

Howe, H.V. and Chambers, J. 1935. Louisiana Jackson Eocene Ostracoda. Louisiana Geological Survey Geological Bulletin, 5:1-65.

Howe, H.V. and graduate students 1935. Ostracoda of the Arca Zone of the Choctawhatchee Miocene of Florida. State of Florida Department of Conservation, Geological Bulletin 13:1-37. http://ufdc.ufl.edu/ UF00000446/00001/1x.

Kollmann, K. 1960. Cytherideinae und Schulerideinae n. subfam. (Ostracoda) aus dem Neogen des östlichen Österreich. Mitteilungen der Geologischen Gesellschaft in Wien, 51:89-195.

Latreille, P.A. 1806. Genera crustaceorum et insectorum. A. Koenig. Parisiis et Argentorati. https://archive.org/ details/generacrustaceor04latr.

Linnaeus, C. 1758. Systema naturae per regna tria naturae: secundum classes, ordines, genera, species, cum characteribus, differentiis, synonymis, locis. Laurentii Salvii. Holmiae. https://archive.org/details/ cbarchive_53979_linnaeus1758systemanaturae1758

Maddocks, R.F. 1969. Revision of Recent Bairdiidae (Ostracoda). United States Natural Museum Bulletin, 295:1-126.

Maddocks, R.F. 1990. Living and fossil Macrocyprididae (Ostracoda). The University of Kansas Paleontological Contribution, 2:1-404.

Maddocks, R.F. and Steineck, P.L. 1987. Ostracoda from experimental wood-island habitats in the deep sea. Micropaleontology, 33:318-355.

Malinverno, E., Taviani, M., Rosso, A., Violanti, D., Villa, I., Savini, A., Vertino, A., Remia, A., and Corselli, C. 2010. Stratigraphic framework of the Apulian deepwater coral province, Ionian Sea. Deep-Sea Research. Deep-Sea Research. Part II. Topical Studies in Oceanography, 57:345-359.

Malz, H. and Jellinek, T. 1984. Marine Plio-Pleistozän Ostracoden Von SE - Lakonien (Peloponnes, Griechenland). Senckembergiana Biologica, 65:113-167.

Mastrototaro, F., Donghia, G., Corriero, G., Matarrese, A., Maiorano, P., Panetta, P., Gherardi, M., Longo, C., Rosso, A., Sciuto, F., Sanfilippo, R., Gravili, C., Boero, F., Taviani, M., and Tursi, A. 2010. Biodiversity of the white coral bank off Cape Santa Maria di Leuca (Mediterranean Sea): An update. Deep-Sea Research. Part II. Topical Studies in Oceanography, 57:412-430.

Mazzini, I. 2004. Taxonomy, biogeography and ecology of Quaternary benthic Ostracoda (Crustacea) from circumpolar deep water of the Emerald Basin (Southern Ocean) and the S Tasman Rise (Tasman Sea). Senckenbergiana Maritima, 35:1-119.

Medioli, F. 1960. La microfauna ad ostracodi del Calabriano di Talignano Val di taro (Parma). Atti della Società Italiana di Scienze Naturali, 99:207-220. 
Moncharmont-Zei, M., Russo, B., Sgarrella, F., Bonaduce, G., and Mascellaro, P. 1985. Paleoclimatic record from 4 cores (Gulf of Taranto, Ionian Sea). Evidence from Foraminifera and Ostracoda. Bollettino della Società Paleontologica Italiana, 2:21-51.

Montenegro, M.E., Pugliese, N., and Bonaduce, G. 1998. Shelf ostracods distribution in the Italian seas, p. 91101. In Crasquin-Soleau, S., Braccini, E., and Lethiers, F. (eds.), What about Ostracoda. Bulletin du Centre Recherche Elf Exploration Production, Pau.

Müller, G.W. 1894. Die ostracoden des Golfes von Neapel und der angrenzenden meeresabschnitte. Verlag von R. Friedländer und Sohn, Berlin.

Müller, G.W. 1912. Ostracoda. Verlag von R. Friedländer und Sohn, Berlin.

Nachite, D., Bekkali, R., and Martinez-Gallego, J. 1993. Los ostracodos y la evolucion paleoambiental del Plioceno Inferior de la Cuenca de Tetuan (Marruecos N. Occidental). Revista Española de Micropaleontologia, 25:25-61.

Namias, I. 1900. Ostracodi fossili della Farnesina e Monte Mario presso Roma. Palaeontographia Italica, 6:79-114.

Neviani, A. 1906. Ostracodi delle sabbie postplioceniche di Carrubbare (Calabria). Bollettino della Società Geologica Italiana, 25:185-216.

Norman, A.M. 1865. Report on the Crustacea, p. 12-29. In Brady, G.S. (ed.), Reports of deep sea dredging on the coasts of Northumberland and Durham, 1862-64. Natural History Transactions of Northumberland, London.

Pasini,G. and Colalongo, M.L. 1997. The Pliocene Pleistocene boundary stratotype at Vrica, Italy, p. 15-45. In van Couvering, J. (ed.), The Pliocene-Pleistocene boundary and the beginning of the Quaternary. Cambridge University Press, Cambridge, MA.

Passlow, V. 1997. Quaternary ostracods as palaeoceanographic indicators: a case study off southern Australia. Palaeogeography Palaeoclimatology Palaeoecology, 131:315-325.

Peypouchet, J.P. and Nachite, D. 1984. Les ostracodes en Méditerranée nord-occidentale. Ecomed, Association Française des Techniciens du Pétrole, 7:151169.

Pucci, A. 1956. Ostracodi pleistocenici della valle del Tronto. Annali del Museo Geologico di Bologna, 25:153-172.

Puri, H.S. 1954. Contribution to the study of the Miocene of the Florida Panhandle. Part 3: Ostracoda. Florida Geological Survey, 36:215-345.

Puri, H.S. 1957. Notes on the ostracods sub family Cytherideidinae Puri, 1952. Journal of Washington Academy of Science, 47:305-306.

Puri, H.S., Bonaduce, G., and Malloy, J. 1964. Ecology of the Gulf of Naples. Pubblicazioni della Stazione Zoologica di Napoli, 3(suppl.):87-199.
Rosso, A., Vertino, A., Di Geronimo, I., Sanfilippo, R., Sciuto, F., Di Geronimo, R., Violanti, D., Corselli, C., Taviani, M., Mastrototaro, F., and Tursi, A. 2010. Hard and soft-bottoms thanatofacies from the Santa Maria di Leuca deep-water coral province, Mediterranean. Deep-Sea Research. Part II. Topical Studies in Oceanography, 57:360-379.

Ruggieri, G. 1950. Gli Ostracodi delle sabbie grigie quaternarie (Milazziano) di Imola (I). Giornale di Geologia, ser. 2, 21:1-58.

Ruggieri, G. 1954. Iconografia degli ostracodi marini del Pliocene e del Pleistocene italiani. Atti della Società Italiana di Scienze Naturali, 93:561-575.

Ruiz, F., González-Regalado, M.L., Abad, M., Civis, J., González Delgado, J.A., Garcia, M.X.M., Prudêncio M.I., and Dias, M.I. 2008. Pliocene ostracods of Southwestern Europe. Geobios, 41:845-859.

Ruiz, F., González-Regalado, M.L., Baceta, J.G., Pendon, J.G., Hernandez-Molina F.J., Somoza, L., and Diaz del Rio, V. 2000. Los ostracodos infralitorales y circalitorales actuales del norte del Golfo de Cadiz. Geogaceta, 27:235-238.

Sars, G.O. 1866. Oversigt af Norges marine Ostracoder. Forhandlinger i Videnskabs - Selskabet i Christiania, 7:1-30.

Sars, G.O., 1869. Nye dybvands crustaceer fra Lofoten. Forhandlinger i Videnskabs - Selskabet i Christiania, 8:170-174.

Sars, G.O., 1928. An account of the Crustacea of Norway vol. IX: Ostracoda. Bergen Museum, Bergen, Norway.

Savini, A. and Corselli, C. 2010. High-resolution bathymetry and acoustic geophysical data from Santa Maria di leuca Cold Water Coral province (Northern Ionian Sea-Apulian Continental slope. Deep-Sea Research. Part II. Topical Studies in Oceanography, 57:326344.

Scacchi, A. 1835. Notizie intorno alle conchiglie ed a' zoofiti fossili che di trovano nelle vicinanze di Gravina in Puglia. Annali Civili del Regno delle Due Sicilie, 12:75-84.

Sciuto, F. 2003. Dati preliminari sull'ostracofauna pliocenica di Capo Milazzo (Sicilia NE). Bollettino della Società Paleontologica Italiana, 42:179-184.

Sciuto, F. 2005. Ostracodi batiali pleistocenici di Capo Milazzo (Sicilia NE) ed implicazioni paleoambientali. Rendiconti della Società Paleontologica Italiana, 2:219-227.

Sciuto, F. 2009. Bythocythere mylaensis n. sp. (Crustacea, Ostracoda) from Early Pleistocene of Capo Milazzo (NE Sicily). Bollettino della Società Paleontologica Italiana, 48:183-188.

Sciuto, F. 2012. New ostracod species from Lower Pleistocene sediments from capo Milazzo (NE Sicily). Bollettino della Società Paleontologica Italiana, 51:117125. 
Sciuto, F. 2014. Ostracods of the Upper Pliocene-Pleistocene Punta Mazza succession (NE Sicily) with special focus on the family Trachyleberididae SylvesterBradley, 1948 and description of a new species. Carnets de Géologie [Notebooks on Geology], 14:1-13.

Sciuto, F. and Rosso, A. 2008. Distribution pattern of deep-water ostracod assemblages in the Lower Pleistocene sediments from Furnari (Sicily). Bollettino della Società Paleontologica Italiana, 47:33-43.

Seguenza, G. 1880. Le formazioni terziarie nella provincia di Reggio Calabria. Regia Accademia dei Lincei, 3:1-416.

Seguenza, G. 1883a. Gli ostracodi dei periodi terziarii e quaternarii viventi nel mare di Messina. Bollettino della Società Geologica Italiana, 2:57-63.

Seguenza, G. 1883b. II Quaternario di Rizzolo. II Gli Ostracodi. Naturalista Siciliano, 1883, anno II, 11:256-259.

Sissingh, W. 1971. Tricostate Trachileberidinae (Ostracoda) from Neogene-Recent deposits of Europe. Koninklijke Nederlandse Akademie van Wetenschappen ser. B, 74:195-205.

Sissingh, W. 1972. Late Cenozoic Ostracoda in the South Aegean Island Arc. Utrecht Micropaleontogy Bulletin, 6:1-187.

Stalder, C., Spezzaferri, S., Rüggeberg, A., Pirkenseer, C., and Gennari, G., 2014. Late Weichselian deglaciation and early Holocene development of a coldwater coral reef along the Lopphavet shelf (Northern Norway) recorded by benthic foraminifera and ostracoda. Deep Sea Research Part II: Topical Studies in Oceanography, 99:249-269.

Stepanova, A., Taldenkova, E., and Bauch, H.A. 2003. Recent ostracoda from Laptev Sea (Arctic Siberia): species assemblages and some environmental relationships. Marine Micropaleontology, 48:23-48.

Swanson, K.M. and Ayress, M.A. 1999. Cytheropteron testudo and related species from the SW Pacific with analyses of their soft anatomies, relationships and distribution. Senckenbergiana Biologica, 79:151193.

Sylvester-Bradley, P.C. 1948. The ostracode genus Cythereis. Journal of Paleontology, 22:792-797.

Taviani, M., Remia, A., Corselli, C., Freiwald, A., Malinverno, A., Mastrototaro, E., Savini, A., and Tursi, A. 2005. First geo-marine survey of living cold-water Lophelia reefs in the Ionian Sea (Mediterranean Basin). Facies, 50:409-417.

Terquem, O. 1878. Les foraminifères et les entomostracès-ostracodes du Pliocène Supérieur de l'lle de Rhodes. Deuxième Section (ostracodes). Mémoires de la Société Géologique de France, 3:81-135.
Tsapralis, V. 1981. Contribution to the study of Pleistocene of Zakinthos Island, W Greece (Ostracoda Palaeoenvironment). Unpublished PhD thesis, Edition of the University of Patras, Patras, Greece.

Ulrich, E.O. and Bassler, R.S.1904. Systematic paleontology of the Miocene deposits of Maryland. Maryland Geological Survey Miocene Reports, 98-130.

van Harten, D. 1990. Modern abyssal ostracods faunas of the eastern Mid-Atlantic Ridge area in the North Atlantic and a comparison with Mediterranean, $p$. 321-328. In Whatley, R. and Maybury, C. (eds.), Ostracoda and Global events. Chapman and Hall, London.

van Harten, D. and Droste, H.J. 1988. Mediterranean Deep-sea Ostracods, the species poorness of the Eastern Basin as a legacy of an Early Holocene anoxic event, p.721-737. In Ikeya, N., Ishizaki, K., and Hanai, T. (eds.), Evolutionary Biology of Ostracoda: Its Fundamentals and Applications. Elsevier, Amsterdam.

Vertino, A., Sciuto, F., Rosso, A., Sanfilippo, R., Baldanza, A., Di Geronimo, R., Pino, P., Di Geronimo, I., and Viola, A. 2010. Faune batiali del Pleistocene di Scoppo (Messina), p. 54. In Demasi, F. et al. (eds.), Giornate di Paleontologia $X$ edizione. Campus di Arcavacata di Rende, 27-28 Maggio 2010, Università della Calabria.

Whatley, R. and Coles, G. 1987. The late Miocene to Quaternary Ostracoda of Leg 94, Deep Sea Drilling Project. Revista Espanola de Micropaleontologia, 19:33-97.

Whatley, R. and Wall, D.R. 1975. The relationship between Ostracoda and algae in littoral and sublittoral marine environments, p. 173-203. In Swain, F.M. (ed.), Biology and palaeobiology of Ostracoda. Palaeontological Research Institution, Ithaca, NY.

Yassini, I. 1979. The littoral system ostracodes from the bay of Bou-Ismail, Algiers, Algeria. Revista Española de Micropaleontologia, 11:353-416.

Yassini, I. 1980. Répartition des ostracodes dans une série marine régressive d'âge Pliocène dans la région d'Algérie. Revue de Micropaléontologie, 22:89-124.

Yasuhara, M., Grimm, M., Brandão, S.N., Jöst, A., Okahashi, H., Iwatani, H., Ostmann, A., and Martínez Arbizu, P. 2014. Deep-sea benthic ostracodes from multiple core and epibenthic sledge samples in icelandic waters. Polish Polar Research, 35:341-360.

Yasuhara, M. and Okahashi, H. 2014. Quaternary deepsea ostracode taxonomy of ocean drilling program site 980, Eastern North Atlantic Ocean. Journal of Paleontology, 88:770-785. 


\section{APPENDIX 1.}

List of the ostracod species found in the samples belonging to the FC, FM, CR, and GI facies from the Santa Maria di Leuca coral province. For each species the total number of specimens found, separated for living association (bio), fresh-looking specimens constituting the recent association (f) and old-looking specimens constituting the oldest Holocene assemblage (w) are reported, together with their relative percentages (\%).

File available as spreadsheet at palaeo-electronica.org/content/2015/1164-deep-water-ostracods

\section{APPENDIX 2.}

List of the ostracod species found in the samples belonging to the MM and SC/HG facies from the Santa Maria di Leuca coral province. For each species the total number of specimens found, separated for living association (bio), fresh-looking specimens constituting the recent association (f) and old-looking specimens constituting the oldest Holocene assemblage $(w)$ are reported, together with their relative percentages (\%).

File available as spreadsheet at palaeo-electronica.org/content/2015/1164-deep-water-ostracods

\section{APPENDIX 3.}

List of the ostracod species found in the six facies detected in the Santa Maria di Leuca coral province. For each species and for each facies (including living associations: bio, fresh-looking specimens of the recent association: $f$, and old-looking specimens from the oldest Holocene assemblage: $w$ ), the frequence (i.e., the number of samples where that species has been found out of the total number of samples examined) and the total number of specimens found are reported in the first line. Numbers in brackets in the second line indicate the range of relative percentages.

File available as spreadsheet at palaeo-electronica.org/content/2015/1164-deep-water-ostracods 